\title{
The Potential of RFID as an Enabler of Knowledge Management and Collaboration for the Procurement Cycle in the Construction Industry
}

\author{
Yassine El Ghazali', Élisabeth Lefebvre', Louis A. Lefebvre'
}

\begin{abstract}
Among the array of innovative ICTs (information and communication technologies), radio frequency identification technology (RFID) can be considered as a major innovation with the potential to offer many new opportunities for construction companies to improve communication, facilitate teamwork, improve information management skills, and encourage greater cross-fertilization between business processes. Empirical results point to the need of the four participating firms to overcome several procurement issues and bottlenecks in order to gain more substantial competitive advantages and consistently satisfy project owners throughout the entire procurement cycle. An RFID system has the potential to improve real-time document and material tracking and control. But, more importantly, findings suggest that RFID improves the management, sharing, and transfer of knowledge and fosters collaboration through integrated document management, prompt issue management, risk management and efficient decision making.
\end{abstract}

Keywords: rfid; collaboration; knowledge management; procurement cycle; construction industry. 


\section{Introduction}

The construction industry represents one of the key industries contributing to worldwide economic growth (Mastura et al., 2007). It also plays an important economic role in the OECD member countries, as it contributes from $5 \%$ to $9 \%$ of total employment and $5 \%$ to $8 \%$ of gross domestic product (OECD, 2008). The industry relies on a wide array of technical, professional and specialized services (Ergen et al., 2007).

Construction projects face some critical challenges, namely cyclical demands, the fluctuating costs of materials, a significant number of change orders per project, and a rather authoritarian environment based on the chain of command. One of the most serious challenges concerns so-called "silos" or "islands of information" due to the various software applications used by different professions such as surveying, architectural design, and engineering. Furthermore, information systems within many of the contractors' core businesses are usually not integrated (Mak, 200I) and a strong culture associated with day-to-day business processes (i.e., the interchange of site instructions in the form of paper documents, specifications, technical sketches and schemas, and face-to-face meetings) is predominant (Stewart, 2007). In addition, information integration and sharing are generally more complex among construction industry players than in other industries (Betts et al., 1991). It is commonly characterized by lack of trust due to the short duration of construction projects; the high rate of break-ups, misunderstandings and disagreements; fragmentation; and continuous changes at the level of each project team along the construction supply chain (Cheng et al., 20I0). Moreover, barriers to information flow are numerous and mainly originate from the organizational structure, the technical features entailed by the industry's information flow, the need for regulations in managing information, and other cultural complexities ( $\mathrm{Zi}$ etsman, 2007). Likewise, intense competition exists between construction value chains rather than between single organizational entities, pushing company decision makers to search actively for cooperation and collaboration with other construction supply chain players (Borade and Bansod, 2007). To address the issues outlined above and facilitate further collaboration connections, the construction industry's key organizational entities look for more effective and efficient ICTs (information and communication technologies) (Xue, Wang, and Shen, 2007;Adriaanse, 2010).

Among the array of innovative ICTs, radio frequency identification technology (RFID) can be considered as a major innovation with the potential to offer many new opportunities for construction companies to improve communication, facilitate teamwork, improve information management skills, and encourage greater cross-fertilization between business processes (Peansupap et al., 2005; Bowden et al., 2005). The main thrust of this paper is that RFID holds the potential to foster the ongoing collaboration within and between organizations and improve the management, sharing, and transfer of knowledge. This is explored in the specific context of procurement activities in one construction industry supply chain.

This paper is organized as follows. The next section presents an overview of the technological, industrial and theoretical background. Section 3 briefly outlines the methodology used in this study. Results are then discussed in section 4 while concluding remarks are offered in the last and fifth section.

\section{Background}

ICTs are defined as "any technology that facilitates communication and assists in capturing, processing and transmitting information electronically" (Oye, 20I I, p. 9). They permit a strong degree of collaboration and coordination among project actors (Peansupap et al., 2005), triggered by real-time access to information, effective communication, a more concurrent system of construction management, and more integrated construction supply chain processes (Duffy, Graham, and Thomas, 2007). The benefits generated from the adoption of these technologies have been assessed by many researchers, practitioners, and experts. For instance, Bowden et al. (2005) stated that (I) construction time and the capital costs of construction, (2) operation and maintenance costs, (3) defects, (4) accidents, (5) waste (which can be reduced if not partially or totally eliminated), (6) productivity, and (7) predictability will all be boosted by the advent of these technologies. Vanita et al. (2009) carried out a survey to explore the key enablers and benefits of an effective adoption of ICTs to better manage building projects. They found that (I) projects are more successful in terms of budgets and time constraints; (2) clients are more satisfied; (3) project information is available and can be retrieved from multiple locations; (4) the risk of errors and task reworking can be reduced; and (5) significant project results can be achieved and then subsequently consolidated within other projects. Other authors such as Mastura et al. (2007) and Olugbode et al. (2007) highlighted numerous benefits and advantages of deploying ICTs in the construction industry. They state that ICTs allow (I) better planning of subcontractors' provisions, with avoidance of unnecessary hold-ups, (2) improved project planning and management, (3) the development of new markets and worldwide positioning, and (4) significant productivity and performance gains. Taking into account these benefits while facing increased competition, globalization pressures and environmental changes, construction organizations are particularly concerned by the deployment of innovative ICTs. More recently, RFID (radio frequency identification) technology emerges as an innovative ICT that 
could improve their strategic, operational, and tactical processes across a wide range of construction applications.

\section{RFID in the construction industry}

\section{RFID technology}

RFID is positioned as "an emergent technology for real-time tracking of any product, module, system and, eventually, any component as they move along the various layers of supply chains" Bendavid (2008, p. ix) and one of today's "fastestgrowing technologies in terms of scope of application in the next generation of business intelligence" (Chen,Tsai, and Liu, 2008). RFID has also the potential to "revolutionize" supply chain processes (Vijayaraman, Osyk, and Chavada, 2008), in particular with respect to product recalls and reverse logistics (Bardaki et al., 2007) and reduce supply chain uncertainty (Wamba, Lefebvre, and Lefebvre, 2007). These alleged benefits have prompted several organizations to deploy RFID technology (Ngai et al., 2006) and the RFID technology market is expanding exponentially, with global sales expected to reach $\$ 26.88$ billion in 2017 (IDTechEx, 2010). An RFID system is composed of three main devices (Table I):

(I) The RFID tag is a miniaturized chip used to embed the information connected to an object (i.e., serial number). This chip is equipped with an antenna that enables communication via radio frequency waves and thus emits data to the (2) reader or central nervous system. This consists of an antenna and a receiver/transmitter, whose tasks are to control and modulate the radio frequencies as well as to identify and transmit data. (3) Host server equipment (and middleware) controls the interconnection between the reader and the information network and delivers data to the various organizational information systems.

\section{RFID in the construction industry}

The construction industry can benefit from RFID technology (Ren, Anumba, and Tah, 20l I). It is perceived as "one of the most anticipated technologies that will supposedly transform processes across the construction and engineering industries" (Goodrum, McLaren, and Durfee, 2005, p. 292) and whose integration is becoming appropriate for various construction applications (Wing, 2006). Examples of research and industrial pilot projects that have explored the potential of RFID technology in the construction industry are listed in table 2.

In addition, Wen, Zailani, and Fernando (2009), Schultmann et al. (2008) and other authors have investigated the potential of an RFID system in construction activities. They found that it has the potential to (I) improve information exchange between suppliers and contractors; (2) decrease communication efforts by streamlining communication channels; (3) simplify the assignment of construction materials, components and equipment to projects; (4) enhance internal and external production as well as logistical processes; (5) improve jobsite security (emergency alerts or machine switch-

\begin{tabular}{|c|c|}
\hline Research Area & Key Authors \\
\hline $\begin{array}{l}\text { Construction supply } \\
\text { chain management and } \\
\text { logistics }\end{array}$ & $\begin{array}{l}\text { Shin et al. (20II) } \\
\text { Sardroud and Limbachiya (20I0) } \\
\text { Van Gassel and Glenco (2008) } \\
\text { Radosavljevi (2007) } \\
\text { Wang, Lin, and Pao (2007) }\end{array}$ \\
\hline $\begin{array}{l}\text { Tracking and tracing } \\
\text { of materials }\end{array}$ & $\begin{array}{l}\text { Tzeng et al. (2008) } \\
\text { Yabuki and Oyama (2007) } \\
\text { Bosche et al. (2006) } \\
\text { Song et al. (2004) }\end{array}$ \\
\hline $\begin{array}{l}\text { Quality } \\
\text { Control }\end{array}$ & $\begin{array}{l}\text { Wang (2008) } \\
\text { Ergen et al. (2007) } \\
\text { Akinci et al. (2006) } \\
\text { Jaselskis et al. (2006) }\end{array}$ \\
\hline $\begin{array}{l}\text { Inventory } \\
\text { management }\end{array}$ & $\begin{array}{l}\text { Isheng, Huang, and Li (20I I) } \\
\text { Ren, Anumba, and Tah (20I I) } \\
\text { Wing (2006) } \\
\text { Goodrum, McLaren, and Durfee (2005) }\end{array}$ \\
\hline $\begin{array}{l}\text { Life cycle } \\
\text { management }\end{array}$ & $\begin{array}{l}\text { Motamedi and Hammad (2009) } \\
\text { Hammad and Motamedi (2007) } \\
\text { Kiritsis, Jun, and Xirouchakis (2007) } \\
\text { Hentula et al. (2005) }\end{array}$ \\
\hline
\end{tabular}

Table 2: RFID in the construction industry: Examples of research areas and pilot projects

ISSN: 07 I8-2724. (http://www.jotmi.org)

Journal of Technology Management \& Innovation (c) Universidad Alberto Hurtado, Facultad de Economía y Negocios. 


\begin{tabular}{|c|c|c|c|}
\hline Description & Applications & & \\
\hline \multirow{3}{*}{ Tags } & Passive & $\begin{array}{l}\text {-Derive their power from the reader's antenna emitted electromagnetic waves; } \\
\text {-Operate under low frequency (LF), high frequency (HF), and ultra-high frequency (UHF); } \\
\text {-Small in size, cheap ( } 9.5 \phi \text { to } 25.5 \phi) \text {, and long shelf life; } \\
\text {-Low memory capacity ( } 64 \text { bits to I kilobyte); } \\
\text {-Limited read range distance (less than } 10 \text { m for UHF frequency). }\end{array}$ & $\begin{array}{l}\text { Access control } \\
\text { ID badges } \\
\text { Inventory control } \\
\text { Work-in-process tracking }\end{array}$ \\
\hline & Active & $\begin{array}{l}\text {-Embed an integrated battery that allows active transmission; } \\
\text {-Operate under UHF; } \\
\text {-Expensive ( } \$ 20 \text { and more) and short shelf life (up to } 5 \text { years); } \\
\text { - High data bandwidth / memory capacity (up to I } 28 \text { kilobytes); } \\
\text {-Reliable and communicate at a distance of several meters (more than } 30 \mathrm{~m} \text { ). }\end{array}$ & $\begin{array}{l}\text { Containers } \\
\text { Trailer tracking } \\
\text { Valuable asset tracking } \\
\text { People tracking } \\
\text { Road tolling }\end{array}$ \\
\hline & Semi-passive & $\begin{array}{l}\text {-Feed the integrated circuits and sensors using an incorporated built-in battery; } \\
\text {-Operates under UHF; } \\
\text {-Tags' lives depend on the number of times they are interrogated; } \\
\text {-Communicate at a distance of I to } 10 \text { meters. }\end{array}$ & $\begin{array}{l}\text { Cold chain applications } \\
\text { Access control } \\
\text { Asset control during } \\
\text { manufacturing }\end{array}$ \\
\hline \multirow[t]{2}{*}{ Readers } & Fixed readers & $\begin{array}{l}\text {-Known also by the name of interrogator and central nervous system; } \\
\text {-Fixed stand-alone device with a separate antenna; } \\
\text {-Composed of a transmitter, receiver, microprocessor, memory, channel input and output, } \\
\text { controller, communications interface, power; } \\
\text {-Activate tags to extract the encapsulated tag then relay them to the middleware. }\end{array}$ & $\begin{array}{l}\text { Warehouse portals } \\
\text { Warehouse packing } \\
\text { Distribution }\end{array}$ \\
\hline & $\begin{array}{l}\text { Mobile read- } \\
\text { ers }\end{array}$ & $\begin{array}{l}\text {-Same specifications as the fixed reader except they are mobile; } \\
\text {-Two types: mobile and mounted readers; } \\
\text {-Antenna is integrated with the reader. }\end{array}$ & $\begin{array}{l}\text { Warehouses - Picking/ } \\
\text { Slap and ship/ Identifica- } \\
\text { tion }\end{array}$ \\
\hline Middleware & - & $\begin{array}{l}\text {-Software platform; } \\
\text {-Connects the hardware components to the software components; } \\
\text {-Manages RFID equipment (i.e., tracks component failures); } \\
\text {-Processes the data extracted by the readers; } \\
\text {-Interacts with organizations' business management systems. }\end{array}$ & All applications \\
\hline \multirow{4}{*}{ Frequencies } & LF & $\begin{array}{l}\text {-Use passive tags and operate at low frequency }(125-134.2 \mathrm{KHz}) \\
\text {-Low data transfer rate between the tag and the reader; } \\
\text {-Reading range is less than } 0.5 \text { meters. }\end{array}$ & $\begin{array}{l}\text { Access and security } \\
\text { Animal identification } \\
\text { Keyless entry } \\
\text { Contract-less cards }\end{array}$ \\
\hline & $\mathrm{HF}$ & $\begin{array}{l}\text {-Use passive tags and operate at a typical frequency }(13.56 \mathrm{MHz}) \\
\text {-Reasonable data transfer rate between the tag and the reader; } \\
\text {-Reading range up to } 1.5 \text { meters. }\end{array}$ & \\
\hline & UHF & $\begin{array}{l}\text {-Use both passive and active tags; } \\
\text {-Typically operate at } 433 \mathrm{MHz}, 915 \mathrm{MHz} \text { in the U.S., and between } 865.5 \text { and } 867.6 \mathrm{MHz} \text { in } \\
\text { Europe; } \\
\text { - High data transfer rate between the tags and the readers; } \\
\text {-Reading range up to } 100 \text { meters for } 433 \mathrm{MHz} \text { and between } 0.5 \text { and } 5 \text { meters for a range } \\
\text { between } 865 \text { and } 956 \mathrm{MHz} \text {. }\end{array}$ & $\begin{array}{l}\text { Tracking } \\
\text { Logistics } \\
\text { Asset management }\end{array}$ \\
\hline & Microwave & $\begin{array}{l}\text {-Typically operate at } 2.45 \mathrm{GHz} \text {; } \\
\text {-High data transfer rate between the tags and the readers; } \\
\text {-Reading range up to } 10 \text { meters. }\end{array}$ & $\begin{array}{l}\text { Vehicle toll } \\
\text { Asset management }\end{array}$ \\
\hline \multirow{3}{*}{ Standards } & Purpose & -Ensure standardized information across RFID applications; & - \\
\hline & EPC Code & $\begin{array}{l}\text {-Use a sequential codification (Header - EPC Manager number - Object class - Serial } \\
\text { number); } \\
\text {-Comprise five classes (class 0:“Read only” passive tags; class I:“Write-once, read-many” } \\
\text { passive tags; class 2: Rewritable passive tags; class 3: semi-passive tags (Reprogrammable); } \\
\text { class 4: active tags (Reprogrammable); class 5: Readers (Reprogrammable)). }\end{array}$ & All applications \\
\hline & ISO & $\begin{array}{l}\text {-Headed by ISO I8000-RFID Air Interface family of standards; } \\
\text {-Comprise ISO I } 8000-\text { I (Generic Parameters for the Air Interface), ISO I8000-2 (below I } 35 \\
\mathrm{kHz} \text { ), ISO I } 8000-3(\text { I } 3.56 \mathrm{MHz}) \text {, ISO I8000-4 (2.45 GHz), ISO I8000-6 (860 to } 960 \mathrm{MHz} \text {, } \\
\text { ISO I } 8000-7(433 \mathrm{MHz}) \text {. }\end{array}$ & \\
\hline
\end{tabular}

Table I: Some technical characteristics of an RFID system

ISSN: 07 I 8-2724. (http://www.jotmi.org)

Journal of Technology Management \& Innovation (C) Universidad Alberto Hurtado, Facultad de Economía y Negocios. 
offs in emergency zones, check satisfactoriness of safety work clothing, etc.); (6) shrink operation costs; (7) cut down on manual errors; (8) provide real-time product visibility for all supply chain members; (9) diminish project costs; (10) ensure good-quality construction; (II) develop strong partnerships; and (II) expand the market.

\section{Procurement in the construction industry}

Construction procurement management is perceived as a potent way to realize competitive advantages (Barros, Barbosa, and Castro, 2008). It can be defined as "the process required to supply equipment, materials and other resources needed to carry out a project and usually involves subprocesses such as acquisition, purchasing, logistics, monitoring, quality assurance and contract administration" (Stuckhart, 1995). Construction procurement management has to meet the customers' requirements in terms of functional performance, quality, functionality and cost-effectiveness (CIRC, 200I) and relies on procurement strategies (Egbu, Vines, and Tookey, 2003). More specifically, as soon as the project's goals and requirements have been established, its associated risks and constraints quantified, and its area of expertise matrix identified, the right system in keeping with the bestvalue procuring method, known as the procurement system, must be considered and used for awarding construction contracts (Masterman, 2002). Procurement systems used in the construction industries can be classified as (I) the separated system, (2) the integrated system, and (3) the management-oriented system. According to Rosli et al. (2006, p. I), each procurement system is distinguished from the others in terms of "responsibilities allocation, activities sequencing, process, procedure and organizational approach in project delivery."

Once the most suitable procurement system is selected by the project owner, a set of sub-activities involving a large number of project actors (project owners, contractors, suppliers, subcontractors, etc.) are initiated. These activities are bid preparation, bid invitation, bid assessment, contract awards, contract administration and management, project setups, purchasing, logistics management, and materials shipping and reception follow-up. Based on an exhaustive literature review, the traditional procurement system, practiced in the industry for more than I50 years, seems to apply widely in today's world construction market (Tolson, 2007). This method, characterized by the independent accomplishment of engineering and construction work, is the source of many claims and disputes, time and cost overruns, delays in project completion, and failures to achieve project objectives whenever there is a breakdown in the control and management of this system. The construction procurement system seems to be more complex than other industries' procurement systems (Eadie et al., 2007), is knowledge-based and requires accurate and timely information (NCCTP, 2006).
A construction procurement system is also perceived as a fundamental construction value chain activity that, similar to other construction activities, consists of different valueadding actors (suppliers, subcontractors, construction firms, engineering and design firms, consultants, project owners, etc.) and encompasses a wide range of work specialties. These can include piping, electricity, heating, carpentry, painting, insulation, and concrete work. Taking account of the project and its multi-organizational interrelationships, the participating construction organizations must create a dynamic system of networking; that is, develop an effective synergy and collaborate while performing a set of well-structured, organized processes, varying from one construction organization to another, in order to procure the materials, equipment, crafts and services needed to successfully execute the project at a lower cost while precisely respecting its design specifications, quality, quantity, time, and many other contracting constraints.

\section{Collaboration and knowledge management for pro- curement in the construction industry}

Collaboration is characterized by "sharing collective skills, expertise, and understanding, in an atmosphere of openness, honesty, trust and mutual respect, to jointly deliver the best solution that meets their common goals" (Wilkinson, 2005, p. 3). In a supply chain context, inter-organizational collaboration is crucial (Mentzer, 200I) and the gains from such collaboration are derived "from the opportunity to access new markets, new technologies and new skills, to reduce operational costs and product time to market, and to optimize overall supply chain performance" (Eisenhardt and Schoonhoven, 1996, p. 137). Collaboration emphasizes information exchange, integration, and durable commitment, (Henttonen, Pussinen, and Koivumäki, 2012) where the management of intellectual capital and its related knowledge are perceived as the nucleus of the supply chain's effectiveness (Dave and Koskela, 2009) and the basis of its operations (Hansen, 2002).

The concept of knowledge management has been defined in several ways. From a strategic point of view, knowledge management "relates to the processes and infrastructures firms employ to acquire, create and share knowledge for formulating strategy and making strategic decisions" (Zack, 2002, p. 257). From a project point of view, it is defined as "the management activities required to source the knowledge stock, create the enabling environment, and manage the knowledge practices to result in an aligned set of project based knowledge" (Reich, Gemino, Sauer, 2012, p.667). From an operational point of view, Davenport and Prusak (1998, p. 5) describe it as "a fluid mix of framed experience, values, contextual information, and expert insight that provides a framework for evaluating and incorporating new experienc-

ISSN: 07 I8-2724. (http://www.jotmi.org)

Journal of Technology Management \& Innovation (c) Universidad Alberto Hurtado, Facultad de Economía y Negocios. 
es and information." Knowledge is derived from data and information but provides a deeper understanding of a particular problem, context or domain, including both its explicit and implicit dimensions (Bennet and Bennet, 2000). To sum up,"knowledge management attempts to ensure growth and continuity of performance by protecting critical knowledge at all levels, applying existing knowledge in all pertinent circumstances, combining knowledge management in synergistic ways, continuously capturing, managing, and sharing relevant knowledge, and developing new knowledge through continuous learning that builds on internal experiences and external knowledge" (Chen et al., 2008, p.397).

The construction procurement system currently faces many collaborative shortfalls, mainly at the knowledge management level. Figure I illustrates how suppliers, engineering and design firms, consulting organizations, contractors, subcontractors and site owners collaborate at the procurement level. The system is characterized by a lack of integrated information systems within many project actors' core businesses, including vulnerable documentation and information handling and exchange, based on paper documents (Martin, 2004), in addition to sporadic face-to-face meetings (Stewart, 2007).

Other significant challenges arising at the procurement level include (I) inadequate exchange of information and communication; (2) short-term commitments of project players; (3) lack of trust between the contractor and the suppliers; (4) clashes and disagreements; (5) closed relationships and difficulties in sharing best practices, and even project documentation; (6) uncontrolled modifications, changes, and reworks; (7) unclear roles and expectations among some project actors; (8) time and cost overruns; and (9) behavioral complications, showing-off, and assignment of blame among participants instead of a joint focus on solving problems. During the last decade, the integration of ICTs within construction processes has improved certain project collaboration factors, both at the intra-organizational level and within a supply chain context. Examples of these technologies include electronic data interchange (EDI), enterprise resource planning (ERP), supply chain optimization software (SCO), web-based integration systems, and radio frequency identification (RFID) systems. According to Duffy, Graham, and Thomas (2007), these latter resources have the capacity to shrink administrative complexities, promoting firms' interorganizational decision making (Xue et al., 2005), ensuring prompt, real-time coordination and knowledge sharing (Honarpour, Jusoh, and Nor, 2012), and standardizing many processes and procedures within the construction supply chain (Harry, Choi, and Lee, 2007; William, 2006). However, based on an extensive literature review, there is limited research regarding the potential of an RFID system in the monitoring, resolution, and expansion of collaborative practices mainly knowledge management sharing and transfer at the procurement level within a supply chain context - and this is precisely the main objective of this paper.

\section{Research methodology}

\section{Research design}

The design of this research paper corresponds to an exploratory study. This seems suitable for numerous causes. First, the management of construction organizations is generally complex (Williams, Bernold, and Lu, 2007) and the adoption of innovative ICTs still lags considerably behind other industries (Hewage, Janaka, and Jergeas, 2008). This is particularly the case for RFID that has been adopted by construction organizations at a sluggish pace. Secondly, although the pro-

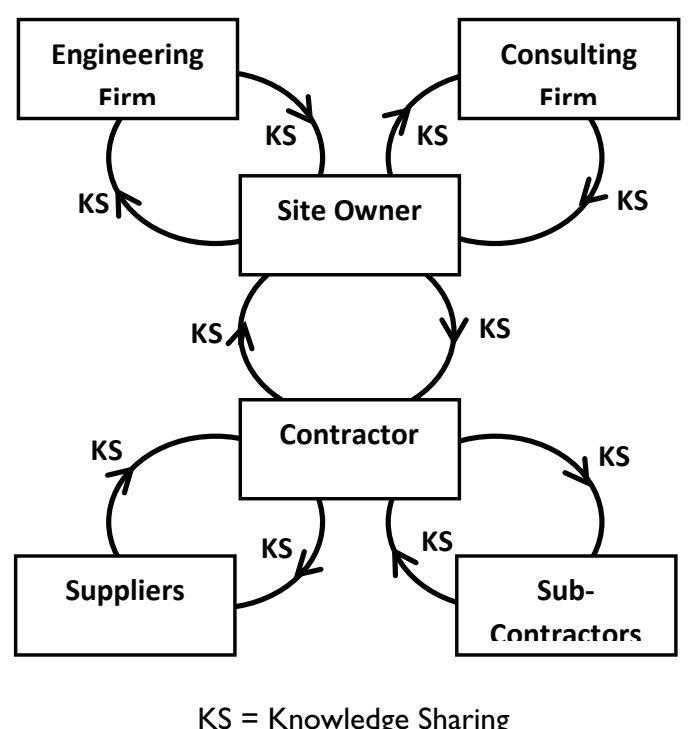

Figure I: Collaboration and knowledge sharing in the procurement activity

ISSN: 07I 8-2724. (http://www.jotmi.org)

Journal of Technology Management \& Innovation (c) Universidad Alberto Hurtado, Facultad de Economía y Negocios. 
ject procurement cycle in the construction industry represents a significant portion of any given construction project, it remains under-explored. Third, RFID achieves its greatest ability when several supply chain layers are connected to each other. This is not the case in the existing published research, which mainly focuses on purchasing or on warehousing activities rather than considering the entire construction project procurement cycle.

This research study attempts to explore the structure, management procurement strategies, as well as the dynamics of the ongoing collaboration among the four organizations on which this research emphasizes. More specifically, it examines how RFID technology could potentially be used to handle existing procurement cycle collaboration issues throughout the various construction project life cycle stages and across the numerous layers of the construction supply chain.

\section{Participating companies}

The field study comprises one construction supply chain with four layers, namely a local firm referred to as Firm $X$ (Contractor), a first-tier supplier specializing in prefabricated pipes (Firm Y), a second-tier supplier specializing in piping raw materials (Firm V), and a job-site owner (Firm Z). Table 3 gives a more detailed description of these four organizations.

\begin{tabular}{|l|l|}
\hline Firms & Description \\
\hline Firm X (Con- & $\begin{array}{l}\text {-Tackles world-class projects in different } \\
\text { industry segments: transportation, civil, mining, } \\
\text { tractor) } \\
\text {-ISO 900I, ISO I400I, and OHSAS I800I } \\
\text { certified. }\end{array}$ \\
\hline Firm Y (Fabri- \\
cation Shop) & $\begin{array}{l}\text {-Leading piping fabrication shop; specializes in } \\
\text { providing industrial contractors with carbon } \\
\text { steel, stainless steel, or any other alloy piping } \\
\text { systems of various bore sizes, schedules, types, } \\
\text { and configurations; }\end{array}$ \\
-Adheres to a large set of quality programs, \\
codes and standards (i.e., ISO 900I, ISO I400I, \\
OHSAS I800I, etc...)
\end{tabular}

Table 3: Description of participating firms

\section{Data collection}

Six phases were conducted in the field research, as illustrated in table 4.

The first phase of this research consists of determining the motivations for, and the potential improvements behind, the adoption and implementation of RFID technology when tracking materials shipped from Firm $V$ (Supplier), which are going to be used to prefabricate pipes within Firm Y (Fabrication Shop) and then installed within Firm Z (Project Owner) by Firm $X$ (Contractor), along with their corresponding engineering designs and documentation.

Phase 2 consists of identifying and analyzing the network that supports the product value chain (PVC). In phase 3, the critical activities of the PVC are selected and analyzed in depth. Phase 4 corresponds to the business process mapping of selected critical activities. We have retained a processbased perspective since such a perspective permits "a more dynamic description of how an organization acts" (Magal, Feng, and Essex, 200I, p. 3). Moreover, this emphasis on the process will allow the construction organizations to move away from traditional functional structures to concentrate on the creation of value. It entails a robust focus on "how work is done within an organization" (Davenport, 1993, p. 5 ) and between organizations. In phase 5, major collaboration issues, including conceptual, technological, contextual, organizational, and inter-organizational issues, are determined mainly with respect to the flow of information and documents and to the flow of materials, and their potential improvement using RFID technology, which is assessed in phase 6. Between these two phases, technological scenarios can be built based on multiple case studies, empirical findings, and focus group outputs. They correspond to collective concerns on the part of the different organizations participating in the project procurement cycle, detailing how the technology really works, the existing organizational and inter-organizational infrastructures that will employ the upcoming RFID system, and the principal elements that will both facilitate collaboration and settle inter-organizational resistance.

Three main sources of empirical evidence were examined and analyzed to permit triangulation (Yin, 1994; Miles and Huberman, 1994):

(I) Publicly available information in order to gain a better a priori understanding of the construction industry and its specific characteristics. More specifically, information regarding the adoption of ICTs (including the RFID pilot projects and current applications) was closely examined.

(2) Multiple on-site observations within Firm X, Firm Y, and

ISSN: 07 I8-2724. (http://www.jotmi.org)

Journal of Technology Management \& Innovation (c) Universidad Alberto Hurtado, Facultad de Economía y Negocios. 
Table 4: Research phases

\begin{tabular}{|l|l|}
\hline $\begin{array}{l}\text { Research } \\
\text { Phases }\end{array}$ & \\
\hline Phase I & $\begin{array}{l}\text { Determining the motivations for, and the potential } \\
\text { improvements behind, the adoption and implementa- } \\
\text { tion of RFID technology }\end{array}$ \\
\hline Phase 2 & $\begin{array}{l}\text { Identifying and analyzing the network that supports } \\
\text { the product value }\end{array}$ \\
\hline Phase 3 & $\begin{array}{l}\text { Selecting critical PVC activities and analyzing them } \\
\text { in depth }\end{array}$ \\
\hline Phase 4 & $\begin{array}{l}\text { Mapping the detailed processes of the selected } \\
\text { activities }\end{array}$ \\
\hline Phase 5 & $\begin{array}{l}\text { Determining major collaboration and knowledge } \\
\text { management issues }\end{array}$ \\
\hline Phase 6 & $\begin{array}{l}\text { Assessing the corresponding potential for improving } \\
\text { collaboration and knowledge management with RFID }\end{array}$ \\
\hline
\end{tabular}

Firm V's plants and the Firm Z's job site. Internal documents such guidelines, directives, and procedures were also analyzed.

(3) Semi-structured interviews based on open-ended questions with key professionals, managers, and other employees at different organizational levels. Participants and their roles in the four organizations are presented in table 5.

Data obtained from the three sources mentioned above was thoroughly analyzed and iteratively cross-validated during the field research that was conducted over a two- year period.

\section{Preliminary results of the field study}

\section{Current procurement cycle and corresponding processes}

The current procurement cycle involves the collaboration of several disciplines and departments within four firms: Firm V, Firm Y, Firm X, and Firm Z. These firms rely on a traditional system, where an engineering firm prepares the engineering phase, then the construction phase is accomplished by the contractor (Firm X), in collaboration with Firm Y, Firm V, and Firm $Z$. The procurement flow involves the following steps. At the beginning of the cycle, the procurement strategy is selected; the project bid is prepared, and then dispatched to the various interested project bidders. The second, third, fourth, and fifth steps of the cycle, described in detail in the following sections, depend on the contract administration, project planning and preparation, materials purchasing, materials shipping, and materials reception activities.

As stated in section 3.2, the project owner (Firm Z) runs
Table 5: Participants and their roles

\begin{tabular}{|l|l|}
\hline Firm & Participants \\
\hline Firm X & $\begin{array}{l}\text { Executive, Project Sponsor, Project Manager, } \\
\text { Operational Manager, Purchase Coordina- } \\
\text { tor, Field Engineer, Quality Engineer, Project } \\
\text { Controller }\end{array}$ \\
\hline Firm Y & Operational Manager, Purchase Coordinator \\
\hline Firm Z & Contract Administrator, Operational Manager \\
\hline Firm V & Warehouse Manager, Operational Manager \\
\hline
\end{tabular}

an oil and gas refinery. Every year, it is responsible for many construction and maintenance projects, ranging from US $\$ 100,000$ to billions of dollars, especially in the case of large, complex expansion projects. In order to win these projects and maintain a leading position in the market, construction contractors' bids must respect the project budget, provisions for quality control, and a tight operating schedule, in addition to satisfying the project owner's objectives and standards. In the same way, the materials supplier (Firm V) must satisfy the prefabricated pipe supplier (Firm Y), and both Firm $Y$ and Firm $V$ must satisfy the construction contractor (Firm $X)$.An in-depth analysis of the situation shows that there is a "domino effect" across this cycle, where a high standard of collaboration in terms of information and materials flows within these four organizations is essential for the survival of Firms X, Y, and V, and where the output of these collaborative tasks will have a strong effect on the perception of the project owner at the point when it selects the project winner.

Based on the interviews undertaken, the procurement processes seem to be similar across these organizations, although there are some minor managerial disparities. The collaborative procurement process workflow is described in detail in figure 2 , which is followed by a list of the main collaborative issues identified based on on-site observations and previous interviews.

\section{Collaboration issues during the procurement cycle}

The results obtained from these multiple case studies show that the materials procurement cycle, which involves many departments and organizations, has led to the introduction of many beneficial practices that have successfully reduced overall costs while building up convincing, trusting, and durable relationships between the parties involved. Some examples include the involvement of suppliers (Firm $\mathrm{V})$ and (Firm Y) early during the procurement cycle by the contractor (Firm $\mathrm{X}$ ) to estimate the costs of materials and 
prefabricated pipes. Further improvements were also noted in the transparent way of exchanging information, the avoidance of an environment of dishonesty and fear, and finally, the intra- and inter-organizational physical support that exists among these firms. However, based on the interviews with key participating project players, there are a number of issues affecting the project procurement cycle, mainly involving the following two flows: (I) the information and document flow, and (2) the material flow. Table 6 and Table 7 describe the main collaborative problems extracted during the interviews, which necessitate immediate action to build a stepping stone for long-term, effective collaboration among these firms.

We will start with the first block of issues: managing information and documents, namely (I) contractual documents, including the tendering package, the contract, invoices, etc.; (2) design documents, comprising the plans, marks, drawings, and specifications; and (3) project management documents, consisting of the estimation, project scheduling, cost control reports, memos, minute meetings, etc. All of these flows are based on a mixture of traditional methods where information is provided via an array of disconnected sources.

Moreover, the management and dispatching of this wide assortment of documents is complex. More specifically, some of these documents are produced manually (by hand), scanned, and then transferred via e-mail attachments or fax. These documents are normally stored in the company server, using a central repository of project documents; however, this is not always the case. Among the four participating firms, key project players store some of these documents on their personal computers, which can create a sense of frustration among the other collaborating members. Furthermore, the slogan "Garbage in, garbage out" applies, regrettably, since the key project players often save documents that do not necessarily correspond to the last version of the file that they share with other players. Such practices can result in time losses and even lead to the creation of documents that are full of mistakes and errors. Figure 3 illustrates how the four organizations handle their documents and communicate with each other.

The material flow level, both intra- and inter-organizationally, represents the second collaborative challenge. The empirical evidence uncovered a series of obstacles and problems that affect the transparency of materials management processes, the project performance, inter-firm relationships, and the mutual organizational benefits. More specifically, based on multiple on-site observations, it has been noted that there can be substantial movements of materials, and hence transactions, putting extra demands on the shipping and receiving processes, which unfortunately depend on manual and semiautomatic techniques. Likewise, there is a lack of real-time visibility, which is necessary to smooth out consecutive processes and improve the visibility of the players concerned, such as the purchase coordinator or the warehouse manager, thus maximizing the efficient use of space, materials, equipment, staff, and the related information.

\section{Improvements using RFID technology}

\section{Proposed RFID solution:A document and material tracking solution}

The retained RFID scenario is designed to offer a comprehensive solution that will enable participating organizations to overcome the main collaboration issues in the two procurement cycle flows discussed, namely the information and document flow and the material flow. Document flow solution: Even though numerous offices are using electronic documents, original documents are still necessitated. Looking for a specific file among a huge quantity within a sizeable area is perceived a time-consuming task. The aim of using RFID technology is thus to effectively identify, monitor, and track any contractual, design, or project management document, whether electronic or hard copy. More specifically, this will allow project participants to keep tracking of the documents numerous versions and their associated metadata (i.e. storage date, storing user), to provide strong indexing capabilities hence smoothing the retrieval activity, to ensure that the documents are stored within the appropriate directory within the database and to strengthen security control features by monitoring privileges and documents workflow.

Figure 4 illustrates the proposed RFID system setting as agreed upon by participating firms:

- An identification (ID) card embedding a passive RFID chip will be used to identify each project member;

- A UHF passive RFID label, in the form of a sticker, will be attached to each file or document;

- $\quad$ An RFID file and document tray reader will be used by the document manager, the project administrator or assistant project administrator, and the project secretary to initially register and record (by simply scanning the

label) engineering and design documents, invoices, and project management documents. Hand-held RFID readers may be used to scan the archived documents;

- $\quad$ Fixed RFID readers will be positioned at the main offices' entrances, exits, and corridors. This step will facilitate the monitoring of each file, document, or document box and maintain a full movement history;

- $\quad$ RFID middleware taking the form of a web-based application, consisting of document management tracking software, will permit the tracking of both hard copy and electronic documents, either at the intra-organizational level over the intranet or with other organizations via the Inter- 


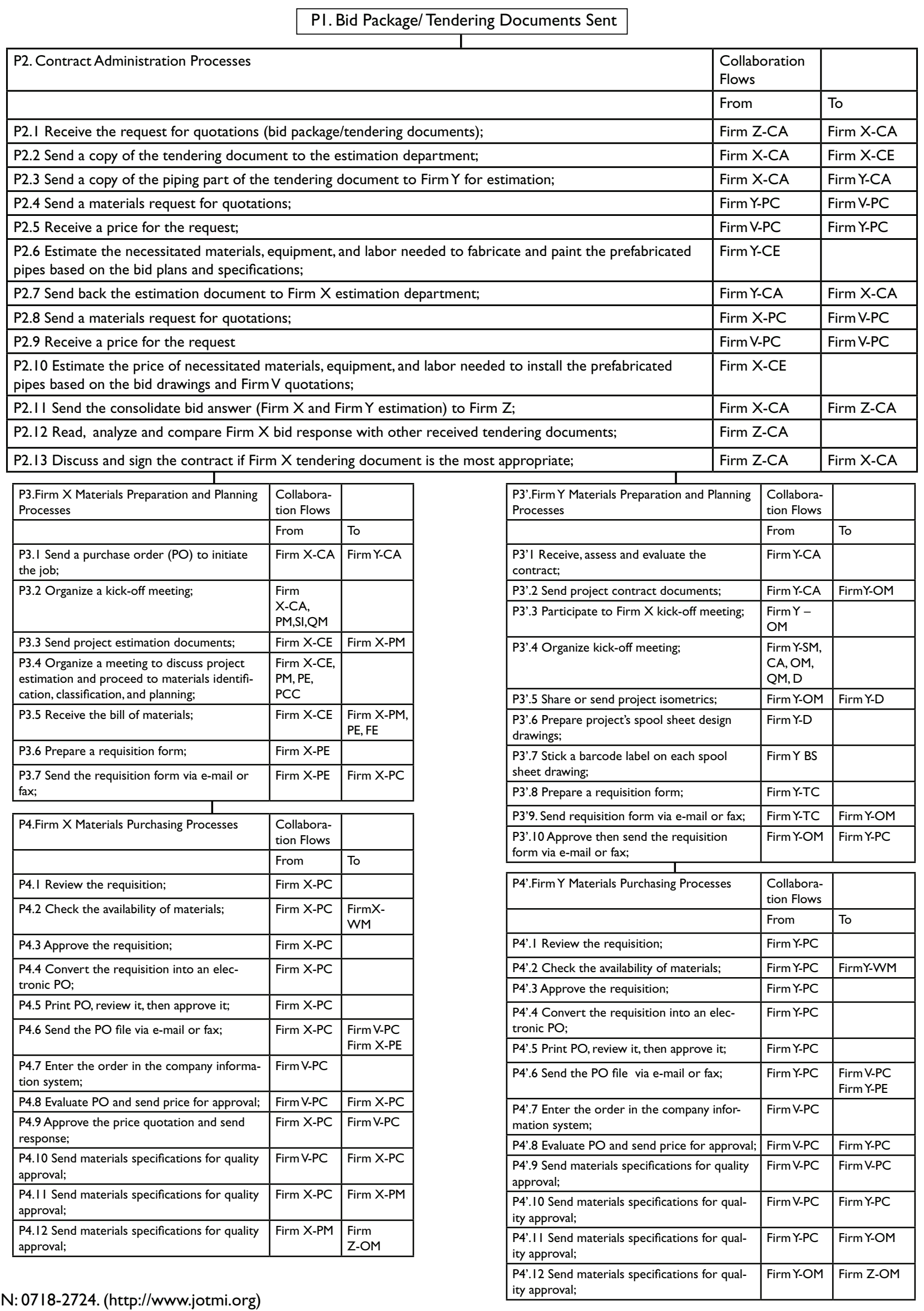




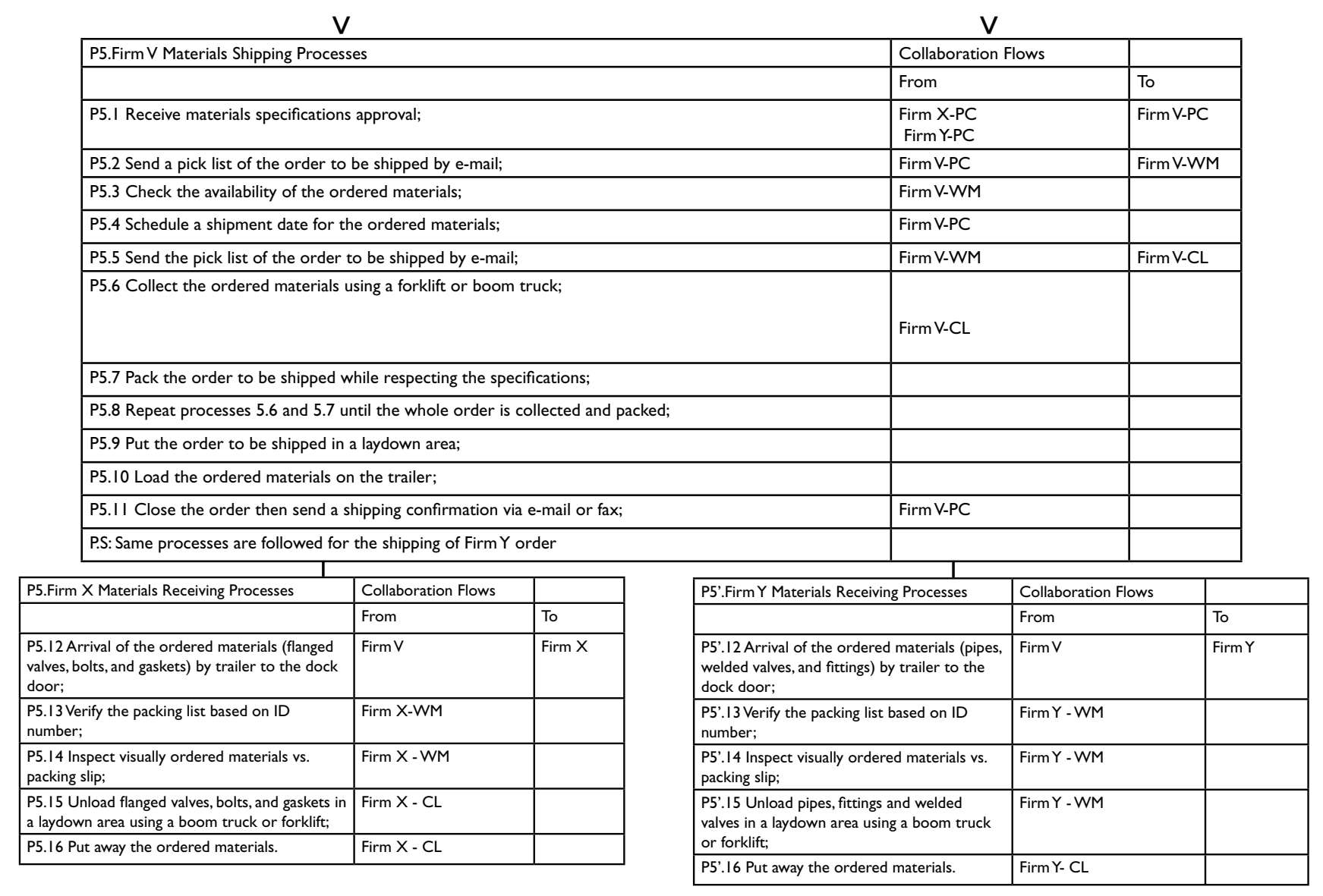

$\mathrm{CA}=$ Contract Administration, $\mathrm{CE}-$ Chief Estimator; $\mathrm{PM}=$ Project Manager, $\mathrm{OM}=$ Operation Manager, $\mathrm{PC}=$ Purchase coordinator, $\mathrm{PE}=\mathrm{Project}$ Engineer, $\mathrm{PCC}=$ Project Controller, FE= Field Engineer, $\mathrm{QM}=\mathrm{Quality}$ Manager, $\mathrm{BS}=$ Barcode Specialist, $\mathrm{TC}=$ Technician, $\mathrm{D}=\mathrm{Drafter}$, WM=Warehouse Manager, $\mathrm{CL}=$ Clerk

Figure 2: Procurement intra- and inter-organizational collaboration flows

net. It will also permit the storage of project documents and facilitate sharing among participants;

- A mainframe server that permits to project participants to have access remotely to the RFID document management tracking application while a Primary Domain Controller (PDC) server controls project accounts and handles the access to computer resources. Finally, a Back-up Domain Controller (BDC) server used to copy all data embedded within the PDC master accounts database. Ethernet and internet networks will permit communication among the different participants.

Material flow solution: As mentioned previously, the material management processes operate across the supply chain. However, the shipping and reception processes are conducted independently, which results in a lack of communication, excessive operating costs, redundant inventory, and low labor productivity. For instance, as stated by the quality engineer at Firm $X$, the inspection process during the reception phase are now carried out visually, may be done too quickly and even overlooked by some clerks. The current situation leads to substantial losses if defects are discovered after putaway and prior to fabrication.

Adopting the RFID system will however lead to the standardization of this process. More specifically, the quality engineer or the inspection clerk will have to approve the inspection phase automatically using the hand-held RFID reader, notifying Firms $V$ and $X$ 's project managers automatically and in real time if non-conformities are found. In addition, the RFID system will enable clear visibility of materials during the shipping and reception processes, eliminating many manual comparisons, as mentioned by Firm X's warehouse manager in Table 7 (M-SI3). It will also facilitate the purchase coordinator's task whenever he has to approve a requisition, since the system middleware will be used as a dashboard, indicating where he can extract, view, and subsequently verify the availability of the required materials (M-SI). Automating the shipping and reception processes will also cut down on manual counting errors (M-SI2) and lead to efficient,

ISSN: 07 I8-2724. (http://www.jotmi.org)

Journal of Technology Management \& Innovation @ Universidad Alberto Hurtado, Facultad de Economía y Negocios. 


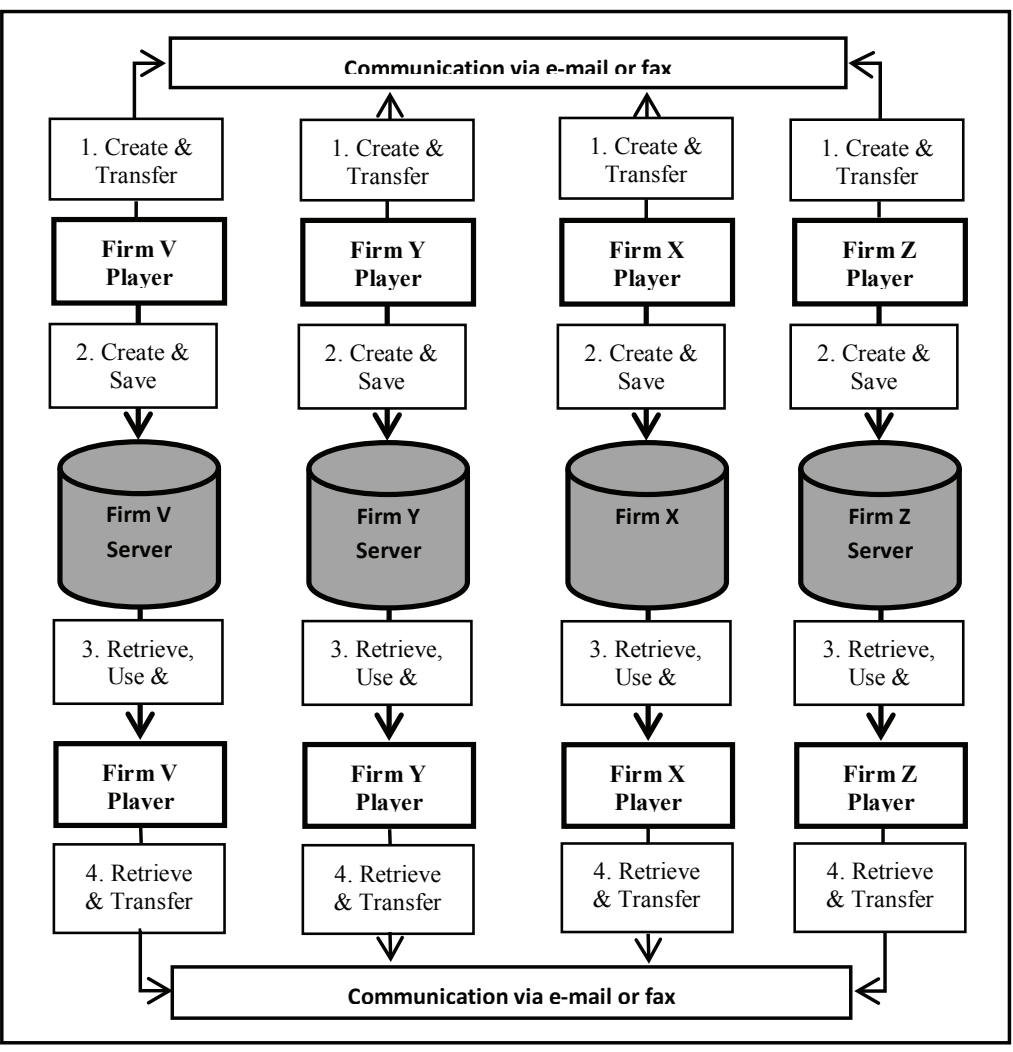

Figure 3: Information and document flows across the procurement cycle

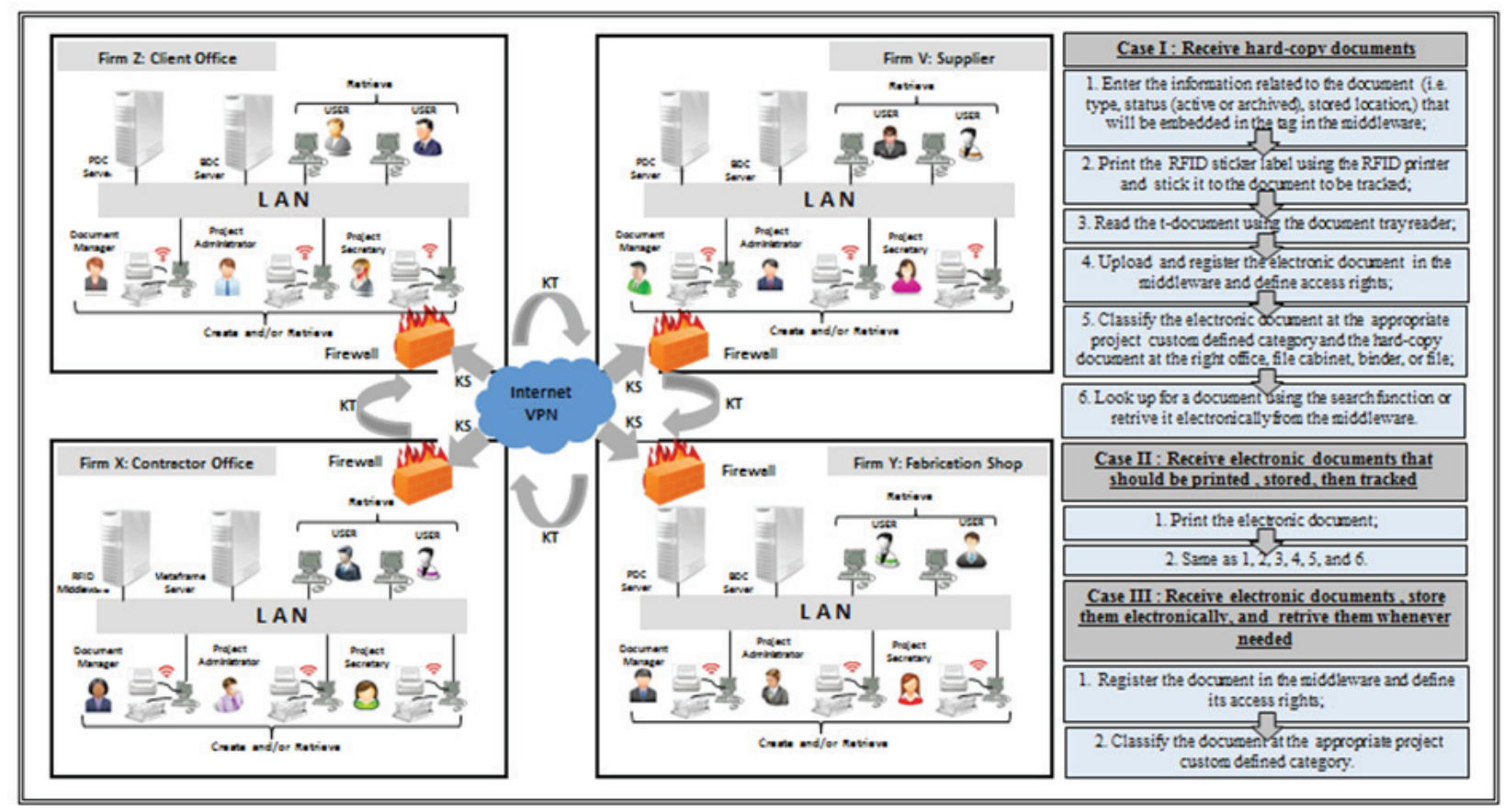

Figure 4: RFID-enabled knowledge management integration in the procurement cycle KS = Knowledge Sharing; KT $=$ Knowledge Transfer

ISSN: 07 I8-2724. (http://www.jotmi.org)

Journal of Technology Management \& Innovation (c) Universidad Alberto Hurtado, Facultad de Economía y Negocios. 


\begin{tabular}{|c|c|c|}
\hline Comments about Information and Documentation Flow Collaboration Problems & Revealed by & $\begin{array}{l}\text { Related Pro- } \\
\text { cesses }\end{array}$ \\
\hline $\begin{array}{l}\text { I\&D-SI. "The project owner's contract administrator or project manager sometimes forgets to send a } \\
\text { request for quotations (RFQ)/tendering document. This can delay the entire project." }\end{array}$ & $\begin{array}{l}\text { Firm Z } \\
\text { Contract Admin }\end{array}$ & PI \\
\hline $\begin{array}{l}\text { I\&D-S2 "Missing information and documents can be noted during and at the end of the project since the } \\
\text { project manager, engineer, quality controller or other project participants save the documents within } \\
\text { their hard disk instead of within the company project server files." }\end{array}$ & $\begin{array}{l}\text { Firm } X \\
\text { Project Sponsor }\end{array}$ & $\begin{array}{l}\text { P2.6. P2.9, } \\
\text { P2.10, P3.3, } \\
\text { P3.6, P3'.6 }\end{array}$ \\
\hline $\begin{array}{l}\text { I\&D-S3. "Delays can be caused while trying to figure out the number and specifications of Requests } \\
\text { for Quotations (RFQs) or purchase orders (POs) issued by the contract administrator. This is due, for } \\
\text { instance, to a limited right of access and the use of the right kind of system to incorporate this kind of } \\
\text { information." }\end{array}$ & $\begin{array}{l}\text { Firm Z Opera- } \\
\text { tional Manager }\end{array}$ & $\begin{array}{l}\text { PI, P2.4, P2.8, } \\
\text { P3.I,P3'9 }\end{array}$ \\
\hline $\begin{array}{l}\text { I\&D-S4."A project player or a group of project players must always wait for someone else's approval } \\
\text { before moving on to a further phase. One of the best illustrations of this is when the engineering firm } \\
\text { responsible for preparing tendering documents plans or waits for the project owner's approval, or when } \\
\text { the contractor waits for the approval of materials specifications by the project owner, or even internally, } \\
\text { when the project engineer waits for the purchase coordinator's approval, etc." }\end{array}$ & $\begin{array}{l}\text { Firm } X \\
\text { Project } \\
\text { Manager }\end{array}$ & $\begin{array}{l}\text { P3'.9, P4.8, } \\
\text { P4.9, P4.10, } \\
\text { P4.II, P4.I2, } \\
\text { P4'8, P4'9, } \\
\text { P4'I0, P4'II }\end{array}$ \\
\hline $\begin{array}{l}\text { I\&D-S5. "Non-sharing of a document with a key project player, wh } \\
\text { personal reasons or because the sender simply judges that it is nc } \\
\text { causes a lack of respect for the initial approved channel of comm }\end{array}$ & \begin{tabular}{|l|} 
Firm $X$ \\
Field Engineer
\end{tabular} & $\begin{array}{l}P 2.2, P 2.3, P 2.7, \\
2.11, P 3.3, P \\
3 ' .2\end{array}$ \\
\hline $\begin{array}{l}\text { I\&D-S6."Lack of assessment on the part of the project owner, contractor, and supplier of the needs } \\
\text { faced by all the key project players due their non-involvement in the daily, weekly, or monthly face-to- } \\
\text { face meetings, and the non-existence of a technological tool to flag critical project events, except e-mails } \\
\text { or the telephone." }\end{array}$ & $\begin{array}{l}\text { Firm } \mathrm{X} \\
\text { Project Sponsor }\end{array}$ & $\begin{array}{l}\text { P3.4, P3'.3, } \\
\text { P3.7, P3'.9, } \\
\text { P4.6, P4'.6 }\end{array}$ \\
\hline $\begin{array}{l}\text { I\&D-S7."With the exception of the company planning software or e-mails shared between the project's } \\
\text { key players, there is no communication software permitting the agents to know, for instance, the status } \\
\text { of requested permits or licenses. Hence, there is a lack of visibility at that level." }\end{array}$ & $\begin{array}{l}\text { Firm X } \\
\text { Project Manager }\end{array}$ & $\begin{array}{l}\text { P3.7, P3'.9, } \\
\text { P4.6, P4'.6 }\end{array}$ \\
\hline $\begin{array}{l}\text { I\&D-S8. "Each member of the project team has difficulties in determining the last version of a document } \\
\text { since it is manually entered by naming revisions in the following sequence, RI, R2, R3, R..., and R0 for } \\
\text { the final version, and in some cases, RA for internal revision, RB for external revision, and R00 for the } \\
\text { official revision, and in yet other cases, a project member finalizes version R2, which another member } \\
\text { finalizes in the parallel version R3." }\end{array}$ & $\begin{array}{l}\text { Firm } X \\
\text { Project Control- } \\
\text { ler }\end{array}$ & $\begin{array}{l}\text { P2.6, P2.10, } \\
\text { P3.6, P3'.6, } \\
\text { P3'.8 }\end{array}$ \\
\hline $\begin{array}{l}\text { I\&D-S9."In the case of a conflict between Firm } \mathrm{X} \text { and Firm Y, Firm } \mathrm{X} \text { and Firm V, Firm } \mathrm{Y} \text { and Firm V, or } \\
\text { Firm } \mathrm{X} \text { and Firm Z, key project players have to build a strong file to prove themselves, when sometimes } \\
\text { they will lack access to written proof since the process was conducted through traditional communica- } \\
\text { tion systems such as phones." }\end{array}$ & $\begin{array}{l}\text { Firm } X \\
\text { Project Sponsor }\end{array}$ & $\begin{array}{l}2.10 \\
3 \prime .6 \\
3 ; .8 \\
24.6\end{array}$ \\
\hline $\begin{array}{l}\text { I\&D-SIO. "During the first I5\% of each project, project engineers and managers face a significant number } \\
\text { of scope changes, requiring prompt coordination with the purchasing department to make the necessary } \\
\text { adjustments, especially in cases where the materials have already been ordered." }\end{array}$ & \begin{tabular}{|l} 
Firm Y \\
Purchase Coor- \\
dinator
\end{tabular} & \begin{tabular}{|l|} 
P3.3, P3.4, \\
P3'.4, P3.5, \\
P3.6, P3.7, P4.9, \\
P4.10 \\
\end{tabular} \\
\hline $\begin{array}{l}\text { curred while trying to look for the right printed or digital document either } \\
\text { izational level." }\end{array}$ & $\begin{array}{l}\text { Firm X } \\
\text { Project Manager }\end{array}$ & $\begin{array}{l}\text { P2.2, P2.3, P2.8, } \\
\text { P2.II, P3.I }\end{array}$ \\
\hline $\begin{array}{l}\text { I\&D-SI2."The lack of precise definitions, or a detailed and clear responsibility matrix where all key } \\
\text { project players' responsibilities and tasks are set out, can cause problems." }\end{array}$ & $\begin{array}{l}\text { Firm Y Ope. } \\
\text { Manager }\end{array}$ & P3.4, P3'.4 \\
\hline $\begin{array}{l}\text { I\&D-SI3. "The existence of a lag prior to knowing something for sure; thus risks are incurred in assess- } \\
\text { ing the project on the part of the given project's key players." }\end{array}$ & \begin{tabular}{|l|l} 
Firm $X$ \\
Project Manager \\
\end{tabular} & \begin{tabular}{|l|} 
P3.4, P3'.4, \\
P4.8,
\end{tabular} \\
\hline $\begin{array}{l}\text { I\&D-SI4. "There is a need for a system to permit the measurement of procurement cycle performance; } \\
\text { i.e., the number of issued RFQs, the number of complaints, and the time taken to perform a task, etc." }\end{array}$ & $\begin{array}{l}\text { Firm } X \\
\text { Executive }\end{array}$ & $\mathrm{PI}, \mathrm{P} 2.4, \mathrm{P} 2.8$ \\
\hline $\begin{array}{l}\text { I\&D-SI5. "Sometimes we are disappointed because we do not want to get involved in a decision that } \\
\text { was taken jointly between Firm } X \text { and Firm } Y \text { even if we know that they didn't exclude us voluntarily." }\end{array}$ & $\begin{array}{l}\text { Firm } X \text { Opera- } \\
\text { tional Manager }\end{array}$ & P3.4, P3'.4 \\
\hline $\begin{array}{l}\text { I\&D-SI6. "There are some documents and information that are very confidential and their access must } \\
\text { be restricted." }\end{array}$ & $\begin{array}{l}\text { Firm X Project } \\
\text { Controller }\end{array}$ & $\begin{array}{l}\text { P2.6. P2.9, } \\
\text { P2.10, P3'.6 }\end{array}$ \\
\hline
\end{tabular}

Table 6: Information and documentation flow problems: Extracted comments

ISSN: 07 I8-2724. (http://www.jotmi.org)

Journal of Technology Management \& Innovation (C) Universidad Alberto Hurtado, Facultad de Economía y Negocios. 


\begin{tabular}{|c|c|c|}
\hline Comments about Material Flow Collaboration Problems & Revealed by & $\begin{array}{l}\text { Related Pro- } \\
\text { cesses }\end{array}$ \\
\hline $\begin{array}{l}\text { M-SI "Whenever I have to approve a requisition and proceed to purchase the required materials, I first } \\
\text { have to verify if the materials that need to be purchased are available in the warehouse. This task is time- } \\
\text { consuming and necessitates the collaboration of the warehouse manager, who generally takes some time } \\
\text { before answering my request." }\end{array}$ & $\begin{array}{l}\text { Firm Y Purchase } \\
\text { Coordinator }\end{array}$ & P4.2, P4'.2 \\
\hline $\begin{array}{l}\text { M-S2 "Once the materials are ordered, the requested reception date is mentioned on the purchase } \\
\text { order that is sent to Firm V. Depending on the size of the project, either I have to follow up with Firm } \\
\mathrm{V} \text {, or in the case of big projects, a person is hired just to follow up with suppliers. This duty is complex } \\
\text { since all confirmations are generally verbal or by e-mail." }\end{array}$ & $\begin{array}{l}\text { Firm } X \\
\text { Purchase Coor- } \\
\text { dinator }\end{array}$ & P5.II \\
\hline $\begin{array}{l}\text { M-S3 "Sometimes there is a delay before receiving payment for the purchased materials, especially in } \\
\text { the case of a sizeable project. This is mainly due to a lack of communication and visibility among the } \\
\text { warehouse manager, the project manager, and the invoicing department." }\end{array}$ & \begin{tabular}{|l|} 
Firm $X$ \\
Project Control- \\
ler
\end{tabular} & P5.16, P5'.16 \\
\hline $\begin{array}{l}\text { M-S4 "The raw materials supplier trailer driver offloads materials in the contractor storage area instead } \\
\text { of offloading them at the right construction site. Because of this, materials can be ordered a second time } \\
\text { and the project can be delayed if no one from the storage area flags the mistake." }\end{array}$ & $\begin{array}{l}\text { Firm } X \\
\text { Project Manager }\end{array}$ & P5.12, P5'.12 \\
\hline $\begin{array}{l}\text { M-S5 "We are all pushing to receive materials while applying the just-in-time strategy to save on the } \\
\text { cost of warehousing. The associated risk here is when the received materials do not correspond to the } \\
\text { order (wrong order, missing materials, or non-respect of the requirements), and we must wait for the } \\
\text { right materials (sometimes up to two or three weeks), pushing us either to change the project planning } \\
\text { (wishing that this activity is not on the project's critical path). On the contrary, the early reception of } \\
\text { materials can cause material re-handling, and the deterioration of the quality of materials." }\end{array}$ & $\begin{array}{l}\text { Firm Y Opera- } \\
\text { tional Manager }\end{array}$ & P5.13, P5'.13 \\
\hline $\begin{array}{l}\text { M-S6 "During the materials reception phase, a quality engineer or the clerk responsible for inspecting } \\
\text { the received materials visually verifies the quantity, the quality and the specifications of the received } \\
\text { materials. However, the inspection phase may be done rapidly or skipped. Receiving a material and } \\
\text { discovering later that it is damaged, or prior to the fabrication phase, is costly since the shop will end up } \\
\text { assuming the responsibility for the damage. Likewise, if the material is needed immediately, this will cause } \\
\text { a delay at the fabrication phase, if not for the entire project." }\end{array}$ & $\begin{array}{l}\text { Firm X } \\
\text { Quality Engineer }\end{array}$ & P5.13, P5'.13 \\
\hline $\begin{array}{l}\text { M-S7 "The raw materials supplier ships materials without any advance notice, or by merely notifying } \\
\text { verbally or via e-mail. The purchase coordinator forgets to notify the other key project players. Receiv- } \\
\text { ing materials unexpectedly does not give us time to get prepared." }\end{array}$ & $\begin{array}{l}\text { Firm Y } \\
\text { Warehouse } \\
\text { Manager }\end{array}$ & $\begin{array}{l}\text { P5.11, P5.12, } \\
\text { P5'.12 }\end{array}$ \\
\hline $\begin{array}{l}\text { M-S8 "All the shipping and reception documents are based on printed papers. This can include invoices, } \\
\text { packing slips, quality inspection documents, etc. At the end of the project, we can finish up with up to } 30 \\
\text { boxes, if not more, of paper documents that take a significant amount of time to process and store and } \\
\text { must be kept over a long period of time." }\end{array}$ & $\begin{array}{l}\text { Firm } X \\
\text { Project Manager }\end{array}$ & $\begin{array}{l}\text { P5.II, P5.I2, } \\
\text { P5..12, P5.I, } \\
\text { P5'.13, P5.I, } \\
\text { P5'.14 }\end{array}$ \\
\hline $\begin{array}{l}\text { M-S9 "Dealing with reverse logistics issues is totally unprofitable for us, since first, there is a penalty for } \\
\text { delays related to materials reception caused by material losses or damages during transportation, or the } \\
\text { shipping of the wrong orders." }\end{array}$ & $\begin{array}{l}\text { Firm VWare- } \\
\text { house Manager }\end{array}$ & P5.14, P5'.14 \\
\hline $\begin{array}{l}\text { M-SIO "When I order materials, I have no idea of the capacity of the warehouse, which complicates the } \\
\text { job of the warehouse manager who will receive them." }\end{array}$ & $\begin{array}{l}\text { Firm X Purchase } \\
\text { Coordinator }\end{array}$ & P4.I, P4'.I \\
\hline $\begin{array}{l}\text { M-SI I "A process for ensuring a proper assignment of the warehouse dock for each trailer is required, } \\
\text { especially in cases where products are put away for storage on the other side of the warehouse." }\end{array}$ & $\begin{array}{l}\text { Firm V Opera- } \\
\text { tional Manager }\end{array}$ & $\begin{array}{l}\text { P5.10, P5.12, } \\
\text { P5'.12 }\end{array}$ \\
\hline $\begin{array}{l}\text { M-SI2 "The automation of shipping and reception processes will allow the realization of adequate, ef- } \\
\text { ficient, and smooth materials loading and unloading compared to manual processes." }\end{array}$ & $\begin{array}{l}\text { Firm Y Ware- } \\
\text { house Manager }\end{array}$ & $\begin{array}{l}\text { P5.I, P5.2, P5.3, } \\
\text { P5.9, P5.I0, } \\
\text { P5.12, P5'.12 }\end{array}$ \\
\hline $\begin{array}{l}\text { M-SI3 "The number of items received is compared to: }(I) \text { the delivery slip to verify that the materials } \\
\text { are received as requested, (2) the packing list to make sure that all the received materials are matched } \\
\text { with the shipped ones, and (3) the purchase order to verify that what was received corresponds to } \\
\text { what was ordered. If ever there is a contradiction between the received materials and the delivery slip, } \\
\text { the packing list, or the purchase order, a non-conformity report should be generated." }\end{array}$ & $\begin{array}{l}\text { Firm XWare- } \\
\text { house Manager }\end{array}$ & P5.13, P5'.13 \\
\hline
\end{tabular}

Table 7: Material flow problems: Extracted comments

ISSN: 07 I8-2724. (http://www.jotmi.org)

Journal of Technology Management \& Innovation (c) Universidad Alberto Hurtado, Facultad de Economía y Negocios. 
smooth, orderly, and standardized unloading and loading. Moreover, by integrating the four firms' processes using an RFID system, the project team will remain informed in real time about the status of the purchased materials, especially when (I) the shipping is initiated, (2) the truck is loaded, and (3) the truck leaves Firm V's dock (M-S7). Likewise, the shipping of wrong orders can be prevented using RFID technology at the source by automatically ensuring that the right orders are expedited to the right destination, thus avoiding reverse logistics issues and consequences (M-S9).

The following technological scenario for the RFID-enabled material flow is retained by the participants: Semi-passive RFID tags are placed on the side of the pallets of purchased materials; Mounted RFID readers are attached to Firms V, $X$, and $Y$ 's forklifts and boom trucks; Fixed readers are positioned at Firm V's exit doors and at Firms $X$ and $Y$ 's entrance doors; RFID middleware is integrated into each firm's WMS. 4.3.2 RFID-enabled collaboration and knowledge management during the materials procurement cycle

An integrated collaborative strategy based on RFID technology among the participating firms is perceived as one of the most appropriate strategy to overcome the issues at both the document and the material management levels as discussed in section 4.2. When integrating the document tracking software (RFID middleware) with the WMS, the RFID system could transform traditional intra- and interorganizational processes into more contemporary standardized practices and procedures aligned across the four firms in the procurement cycle. In other words, a sizeable ratio of non-value-added processes (i.e., administrative inconveniences), as outlined in tables 6 and 7 , will be eliminated, and a significant portion of the other processes will result in a more productive operation; hence, we can create gains by automating and semi-automating those processes. Likewise, project performance will be improved and the transformed organizational processes will become stronger with the retained RFID solution, permitting the procurement cycle, specifically, and industrial construction activities, in general, to operate more effectively and efficiently.

This result can be achieved by, for instance, facilitating the storage and interpretation of all documents and information after their collection at both the intra- and inter-organizational levels, then providing all project team members with real-time, accurate documents. These documents can detail and specify, while sharing responsibility for, the preparation and planning of the entire project by synchronizing the preparation and planning activities with purchasing activities, leading to the creation of a collaborative atmosphere that will keep team members pushing for success. More specifically, a comprehensive, centralized, integrated and structured knowledge management database includes all communications between project team players, such as RFQs, issues, risks, meetings, memos, etc., to be developed. As well, using the RFID system will ensure an organized, standardized manner of transferring knowledge. This will provide an equal learning opportunity for both current and future project participants, since they will acquire the necessary knowledge in a more structured way. Unlike a customary knowledge transfer, which depends on a one-way knowledge flow (document to project player), the system will smooth the process of sharing knowledge either internally or at the interorganizational level, which will in turn enhance the learning curve of the participating organizational players. Likewise, the RFID system will guarantee that the appropriate knowledge is shared and transferred among the participants. In other words, the intra-organizational and inter-organizational knowledge development review process will be effectively monitored following the advent of this technology.

To sum up, the advent of the RFID system will have a positive effect on both document and material flows and will enhance knowledge management. Participants concurred that the system will generate positive impacts on integrated document management, prompt issue management, risk monitoring, and efficient and collaborative decision making (see Table 8).

\section{Integrated document management}

As illustrated in figure 4, RFID system middleware acts as a central repository for all documents or document information, known as metadata, created by the document manager, project administrator, or project secretary at each of the four participating firms. It provides an integrated access gateway permitting quick, reliable and effective document search and retrieval for any given firm's users. Moreover, its web-based functionality will ensure a smooth flow of information across each of the four participants.

From the list of added values addressed by the integration of an RFID system, the following aspects are considered by participants to be the most interesting:

I) Standardization of document management processes, procedures, and sharing practices

Perhaps the most compelling example is represented by the new uniform manner of sharing documents. More specifically, the integration of the RFID system implies that users retrieve the needed document from the RFID middleware since documents sent as e-mail attachments will be automatically rejected. This will also allow users to keep the capacity of their e-mail inboxes low and will thereby avoid the dispatching of unofficial or old versions of the documents to project participants, either within or between firms. Moreover, failure to share a document with a key project player

ISSN: 07 I8-2724. (http://www.jotmi.org)

Journal of Technology Management \& Innovation @ Universidad Alberto Hurtado, Facultad de Economía y Negocios. 


\begin{tabular}{|c|c|}
\hline Integrated Document Management & Resolved issues \\
\hline P1-Standardizes documentation management processes, procedures, and information sharing; & I\&D-S2, I\&D-S5 \\
\hline $\begin{array}{l}\text { P2-Represents the central access and retrieval portal for documents and/or metadata document infor- } \\
\text { mation; }\end{array}$ & $\begin{array}{l}\text { I\&D-S2, I\&D-S11 } \\
\text { I\&D-S9 }\end{array}$ \\
\hline P3-Monitors the workflows of printed and digital documents; & I\&D-S7, I\&D-S8, \\
\hline P4-Tracks printed and digital documents in real time; & M-S8, I\&D-S11 \\
\hline P5-Improves document security controls. & I\&D-S16, M-S13 \\
\hline \multicolumn{2}{|l|}{ Prompt Issue Management } \\
\hline $\begin{array}{l}\text { P1-Improves coordination practices by relying on open technological communication that focuses on } \\
\text { project objectives and on the identification, prevention, or resolution of conflicts and issues during any } \\
\text { phase of a project by sharing them in real time with the concerned project team players; }\end{array}$ & I\&D-S12 \\
\hline $\begin{array}{l}\text { P2-Ensures accurate information, document or material flows by semi-automatically tracking the } \\
\text { status (untreated, treated and unresolved, in process, pending, or resolved) of the issues involving } \\
\text { project team members and provides daily, bi-weekly, or weekly follow-ups on issue status to top } \\
\text { management; }\end{array}$ & I\&D-S4 \\
\hline $\begin{array}{l}\text { P3-Makes a flagged issue the responsibility of every member of the concerned project team and not } \\
\text { just of the project manager by notifying them, monitoring their responses on the system, and alerting } \\
\text { them if no response is made; }\end{array}$ & $\begin{array}{l}\text { I\&D-S1, I\&D-S2, } \\
\text { I\&D-S12 }\end{array}$ \\
\hline $\begin{array}{l}\text { P4-Eliminates surprises during face-to-face meetings by informing and implicating all project team } \\
\text { members concerned in problem solving in real time; }\end{array}$ & \\
\hline $\begin{array}{l}\text { P5- Instantly resolves all issues based on quantitative measurement while reducing reply time delays } \\
\text { and conserving the proper documentation electronically. }\end{array}$ & $\begin{array}{l}\text { I\&D-S1, I\&D-S3, } \\
\text { I\&D-S14 }\end{array}$ \\
\hline \multicolumn{2}{|l|}{ Risk Monitoring } \\
\hline P1-Standardizes risk monitoring procedures for risk documents instantaneously upon identification; & I\&D-S2, I\&D-S13 \\
\hline $\begin{array}{l}\text { P2-Keeps top management and project team players informed about the assessment status of a trig- } \\
\text { gered risk; }\end{array}$ & I\&D-S10, M-S5 \\
\hline $\begin{array}{l}\text { P3-Assembles and monitors all identified risks and their respective status, and presents mitigation } \\
\text { plans in an electronic register; }\end{array}$ & I\&D-S2 \\
\hline $\begin{array}{l}\text { P4-Dispatches documentation automatically detailing all identified risks and their degree of complex- } \\
\text { ity to the project players concerned (right after a meeting, for instance); }\end{array}$ & I\&D-S7 \\
\hline P5-Keeps project planners abreast in real time of any potential risks that will affect their scheduling. & I\&D-S10 \\
\hline \multicolumn{2}{|l|}{ Efficient and Collaborative Decision Making } \\
\hline $\begin{array}{l}\text { P1-Tracks requests detailing the number of issued quotations and keeps the project owner and con- } \\
\text { cerned players on the alert about missing RFQs by automatically sending out e-mails and SMSs; }\end{array}$ & I\&D-S1, I\&D-S3 \\
\hline P2-Develops an effective decision making process based on reliable project reporting; & M-S1, M-S11 \\
\hline $\begin{array}{l}\text { P3-Keeps project players abreast of all the decisions taken in real time by tracking, monitoring, and } \\
\text { communicating them; }\end{array}$ & I\&D-S15 \\
\hline $\begin{array}{l}\text { P4-Ensures absolute involvement and commitment by all concerned with procurement cycle decision } \\
\text { making; }\end{array}$ & I\&D-S5, I\&D-S6 \\
\hline
\end{tabular}


who is supposed to receive it (I\&D-S5) can be averted when (I) the sender forgets to add the person's name to the list, (2) the sender simply feels that it is not important to send it to someone, or (3) the sender has some problems with the neglected recipient, who can then be either eliminated or retained by the RFID system. Additionally, each captured document, or component of document information, will be stored, indexed, and archived in the same way, facilitating and smoothing out the searching and retrieval of documents, thereby expediting the export and transfer functions.

2)Central access and retrieval portal

It was stated at the beginning of this section that the RFID middleware would be the official central repository for the four firms participating in the construction project.

As described in depth in figure 7, the procurement cycle documents enter the repository in three different ways:

(I) by creating a document, tagging it, uploading it, and tracking the printed and electronic versions; (2) by converting the printed documents received to electronic ones while tracking both versions; and (3) by saving the electronic version of the document, printing it, and again tracking both versions, or by choosing to save only the electronic version of the document and tracking it electronically. This new work method will lead to the elimination of some inappropriate practices, such as encapsulating documents within personal computers (I\&D-S2). It will also permit the distribution of the appropriate documents in real time. Moreover, the middleware will detain each of the procurement cycle documents, which will facilitate the building of strong files in case of litigation (I\&D-S9).

3)Workflow monitoring of printed and digital documents Workflow monitoring of printed and digital documents is perceived as the fundamental functionality and even the "nerve center" of RFID middleware, which will allow the four participating organizations to increase the visibility, effectiveness, and control of the document flow throughout the various stages and processes of the procurement cycle. An example of a middleware characteristic is the management of the document's various versions and status, consisting in assigning and clearly identifying a single number for the last version of either printed or digital documents. In addition, the check-in and check-out functions will eliminate the possibility of several people working on the same version simultaneously by locking and forbidding any change in the check-out documents (I\&D-S8). Concerning the second attribute related to the document workflow status, the adoption of an RFID system will permit the user to flag the status of a document (i.e., if the document is in the process of revision, commenting, or approval). This action can be supported by using ad hoc elements such as e-mail notification (I\&D-S7).
4)Improved document security

For printed documents, the RFID system will enable the prompt tracking of printed documents based on the RFID sticker (tag), the RFID file and the document tray reader, as well as the fixed RFID readers, the hand-held RFID reader, and the RFID middleware. It will considerably reduce the time spent by project players looking for project documents, thus decreasing clerical time as well as the overall workload of the entire project team in the four organizations (I\&D-SII). Moreover, using an identification card embedding a passive RFID chip will permit users to recognize the last person who held the document. Project administrators can limit borrowing rights to concerned project players only. Electronic documents will be tracked using the RFID middleware, which assumes the role of document management software. The search function will be based on index terms, document content, the corresponding package, etc. In addition, the system has the ability to track and trace all archived boxes and documents and to destroy them after the termination of the contractual retention schedule (M-S8).

As noted in section I, the construction industry's culture depends on an authoritarian environment that relies on a chain of command. Such environment necessitates access to a control configuration of either hard-copy or electronic documents. For instance, cost progress files must not be visible to all key project players.Another example concerns the memos and executive meeting summaries (I\&D-SI6). These practices can be promptly regulated and controlled by the RFID system. More specifically, whenever a printed document is taken for examination or moved, the project player who took it will be identified, the date and time recorded, and the privileges flagged, depending on the programmed business rules.

\section{Prompt issue management}

Prompt issue management consists of properly defining and strengthening the assignment of responsibilities to the participating firms' project players to prevent conflicts and managing issues proactively, thereby creating a synergistic project-oriented environment where all participants can keep working for the success of their objectives. With the advent of the RFID system, these gains can be quickly realized. This could start with the definition of the project responsibility matrix, which many project managers are accustomed to outline orally. However, using this system, they will be obliged to develop a well-structured written matrix that can be dispatched and shared with all project players, and which will be used subsequently as the base for relaying all issues to each of the concerned persons in real time (I\&D-SI2). This will also send a flagged message to every member of the project team concerned and not just of the

ISSN: 07 I8-2724. (http://www.jotmi.org)

Journal of Technology Management \& Innovation (c) Universidad Alberto Hurtado, Facultad de Economía y Negocios. 
project manager: this includes notification, response monitoring, and alert if no response is made. Likewise, the issue's status will be tracked (untreated, treated and unresolved, in process, pending, or resolved) and follow-up summaries will be provided electronically to top management. It will also eliminate surprises during face-to-face meetings by informing and implicating all project team members involved in problem solving on a timely basis.

Additionally, the adoption of RFID technology will facilitate the immediate calculation of the number of issued RFQs (I\&D-SI and I\&D-S3) by Firm Z's contract administrator. Such advantages will no doubt prevent internal conflicts. More than that, the system will allow clients to measure quantitatively the number of complaints that arise during the cycle and the estimated time taken to address them. These elements will ensure an instantaneous measurement of procurement cycle performance (I\&D-SI4).

\section{Risk monitoring}

In contrast to issue management, where the participating project team members learn to focus on resolving current issues and conflicts, risk management relies on spotting and highlighting future potential risks related to a given project. More than that, the project team analyzes and prioritizes those risks, and finally carries out a strategy to ensure that the right decisions are taken at the right time to mitigate, monitor, or eliminate them throughout the entire project life cycle. The RFID system permits the standardization of risk monitoring procedures because it receives all identified risk documents electronically. Moreover, the RFID technology has the potential to keep top management updated about the assessment status of a triggered risk. For instance, if a wrong or missing order is received or its quality has deteriorated, the related risk is immediately evaluated since it may have an impact on subsequent activities, and its status is shared in real time (M-S5). Moreover, the RFID middleware will be used as the official repository of all the risk documents, mainly by means of a risk register (I\&D-S2). This will facilitate the dispatching of all risk documents instantaneously after their identification, eliminating the current lags (I\&D-SI3), and keeping project planners abreast of any potential risks that might affect their scheduling (I\&D-SI0).

\section{Efficient and collaborative decision making}

Decision making is positively impacted by the advent of the RFID system. It is perceived as the outcome of all the relevant data that has been gathered and analyzed, including facts and proofs, and relies on prompt collaboration at either the intra- or inter-organizational level. Using this system, project decision makers will obtain better quantitative visibility regarding the project procurement cycle. For instance, the number of RFQs issued can be tracked in real time and concerned players will be alerted about missing RFQs by automatically sending an e-mail or an SMS, thereby properly overcoming the difficulties outlined in tables 7 and 8 (mainly M-SI and M-SII). Moreover, this technology will facilitate the development of an effective decision making process, based on reliable project reporting, which will generate valuable solutions that will overcome problems (I\&D-SI and I\&D-S3). Once decisions are made, they will be dispatched and communicated using the RFID middleware to all project players involved, which will enable them to keep abreast of all decisions and eliminate conflicts and disappointments (I\&D-SI5). This will also ensure absolute involvement and commitment on the part of all procurement cycle decision makers (I\&D-S5 and I\&D-S6). Additionally, as stated in section 4.3.2.I, the RFID system will be used as the central repository for all decisions taken.

\section{Conclusion}

This paper attempts to address the lack of research contributions addressing the potential of RFID in the construction supply chain during the project procurement cycle. This constitutes the core motivation for our study. Empirical results point to the need of the four participating firms to overcome several procurement issues and bottlenecks in order to gain more substantial competitive advantages and consistently satisfy project owners throughout the entire procurement cycle. An RFID system has the potential to improve real-time document and material tracking and control. But, more importantly, findings demonstrate that RFID enhances collaboration and knowledge management practices through (I) integrated document management; (2) prompt issue management; (3) enhanced risk and finally (4) efficient decision making.

RFID is particularly suited for tracking and tracing material flows. Empirical data gathered in the specific context of procurement activities in one construction industry supply chain show that RFID is also critical for the management of printed and digital documents throughout their entire life cycle, starting when documents are first created or identified, to the point when they are archived or even destroyed after the termination of the contractual retention schedule (five years in most cases). However, the successful adoption of the envisioned RFID system relies on the capacity of the four participating organizations need to operate as an integrated team, by trusting each other, sharing information and documents, and committing themselves. Contractors could act as the main initiator of RFID adoption by first successfully integrating the technology within their intra-organizational processes and then proposing the implemented solution to either the project owner or the project suppliers and subcontractors. 


\section{References}

ADRIAANSE, A., Voordijk, H., Dewulf, G. (20I0). The use of inter-organisational ICT in United States construction projects.Automation in Construction, 19 (I), 73-83.

AKINCl, B., Boukamp, F., Gordon, C., Huber, D., Lyons, C., Park, K. (2006). Formalism for utilization of sensor systems and integrated project models for active construction quality control.Automation in Construction, I5(2), I24-I38.

BARDAKI, C., Pramatari, K., and Doukidis, G. I. (2007). RFIDenabled supply chain collaboration services in a networked retail business environment. In Proceedings of the 20th Bled eConference eMergence: Merging and Emerging Technologies, Processes, and Institutions, Bled, Slovenia, June 2007.

BARROS, A., Barbosa, P. A. P., and Castro, A. (2008). Decision support framework for supply chain collaboration. In Proceedings of POMS 19th Annual Conference, California, USA, May 2008.

BENDAVID,Y. (2008). Étude des phases en amont des projets d'adoption des technologies RFID pour l'amélioration des chaines d'approvisionnement. PhD Thesis, Montreal, Canada.

BENNET, A., Bennet, D. (2000). Characterizing the next generation knowledge organization. Knowledge and Innovation: Journal of the $\mathrm{KMCl}, \mathrm{I}(\mathrm{I}), 8-42$.

BENNETT, L.F. (2003). The management of construction: A project lifecycle approach. Taylor and Francis Group, Oxford.

BETTS, M., Lim, C., Marthur, K., Ofori, G. (199I). Strategies for the construction sector in the information technology era. Construction Management and Economics, 9(6), 509528.

BORADE, A. B., Bansod, S.V. (2007). Domain of supply chain management -A state of the art. Journal of Technology Management \& Innovation, 2(4), 109-12I.

BOSCHE, F., Teizer, J., Haas, C.T., Caldas, C.H. (2006). Integrating data from $3 D C A D$ and $3 D$ cameras for real-time modeling. In Proceedings of Joint International Conference on Computing and Decision Making in Civil and Building Engineering, Montréal, Canada, June 2006.

BOWDEN, S., Dorr, A., Thorpe, T.,Anumba, C. (2005). Mobile ICT support for construction process improvement. Automation in Construction, I5(5), 664-676.

CHANG, H., Tzeng, G. (2010). A causal decision making model for knowledge management capabilities to innovation performance in Taiwan's high-tech industry. Journal of Technology Management and Innovation, 5(4), I37-I 46.

CHEN, K., Tsai, H., Liu,Y.Y. (2008). Development of the RFID System for nuclear materials management. In Proceedings of the 49th INMM Meeting, Nashville, TN, July 2008.

CHEN, Y.J., Chen, Y.M., Chu, H.C. (2008). Enabling collaborative product design through distributed engineering knowledge management. Computers in Industry, 59(4), 395-409.

CHENG, J.C.P., Kincho, H.L., Bjornsson, H., Jones, A., Sriram, R. (2010). A service oriented framework for construction supply chain integration. Automation in Construction, 19(2), 245-260.

CONSTRUCTION INDUSTRY REVIEW COMMITTEE (CIRC), (200I). Construct for excellence: report of the Construction Industry Review Committee. Hong Kong.

DAVE, B., Koskela, L. (2009). Collaboration knowledge management - A construction case study. Automation in Construction, I8(7), 894-902.

DAVENPORT,T.H. (1993). Process innovation. Harvard Business School Press, Boston.

DAVENPORT,T., Prusak, L. (1998).Working knowledge: How organizations manage what they know. Harvard Business School Press, Boston.

DUFFY, K., Graham, B., Thomas, K. (2007). Assessing the potential for construction collaboration technologies (CCT) in small to medium enterprises in the Irish construction industry. In Proceedings of the 23rd Annual ARCOM Conference, Belfast, UK, September 2007.

EADIE, R., Perera, S., Heaney, G., Carlisle, J. (2007). Drivers and barriers to public sector e-procurement within Northern Ireland's construction industry. ITcon, 12, 103-1 20.

EGBU, C.,Vines, M., Tookey, J. (2003). The role of knowledge management in e-procurement initiatives for construction organizations. In Proceedings of the 19th Annual ARCOM Conference, Brighton, UK, September 2003.

EISENHARDT, K.M. (1989). Building theories from case study research. The Academy of Management Review, 14(4), 532-550.

EISENHARDT, K., Schoonhoven, C.B. (1996). Strategic alliance formation in entrepreneurial firms: Strategic needs and social opportunities for co-operation. Organizational Science, 7(2), |36-|4|. 
ERGEN, E., Akinci, B., East, B., Kirby, J. (2007). Tracking components and maintenance history within a facility utilizing radio frequency identification technology. Journal of Computing in Civil Engineering, 2I(I), I I-20.

GOODRUM, P.M., McLaren, M.A., Durfee, A. (2005). The application of active radio frequency identification technology for tool tracking on construction job sites. Automation in Construction, I5(3), 292-302.

HAMMAD, A., Motamedi, A. (2007). Framework for lifecycle status tracking and visualization of constructed facility components. In Proceedings of the 7th International Conference on Construction Applications of Virtual Reality, Pennsylvania, USA, October 2007.

HANSEN, M.T. (2002). Knowledge networks: Explaining effective knowledge sharing in multiunit companies. Organization Science, I 3(I), 232-248.

HARRY, K.H., Choy, K.L., Lee, W.B. (2007). A dynamic logistics process knowledge based system - An RFID multi-agent approach. Journal of Knowledge-Based Systems, 20(4), 357372.

HENTTONEN, K., Pussinen, P., Koivumäki, T. (20/2). Managerial perspective on open source collaboration and networked innovation. Journal of Technology Management \& Innovation, 7(3), I35-I47.

HENTULA, M., Tonteri, H., Pursula, P., Montonen, J. (2005). RFID in recycling data management of electric and electronic equipment.VTT Industrial System Paper. https://virtual.vtt. fi/virtual/etek/raportti/etek_researchreport.pdf [Accessed January 17, 20I2].

HEWAGE, K.N., Janaka, Y.R., Jergeas, G.F. (2008). IT usage in Alberta's building construction projects: Current status and challenges. Automation in Construction, I7(8), 940-947.

HONARPOUR, A., Jusoh, A., Nor, K. (2012). Knowledge management, total Quality management and innovation: A new look. Journal of Technology Management \& Innovation, 7(3), 22-3I.

IDTECHEX REPORT, (20I0). RFID forecasts, players, and opportunities 2007-2017. http://www.idtechx.com. [Accessed January 17, 2012].

ISHENG, L., Huang, G., Li, H. (20I I). Scenarios for applying RFID technology in construction project management. Automation in Construction, 20(2), I0I-106.
JASELSKIS, E.J., Cackler, E.T., Walters, R.C., Zhang, J., Kaewmoracharoen, M. (2006). Using scanning lasers for real-time pavement thickness measurement. National Concrete Pavement Technology Center Paper, lowa State University.http:// www.ctre.iastate.edu/reports/scanning_lasers_web.pdf. [Accessed January 20, 20I2].

KIRITSIS, D., Jun, H.B., Xirouchakis, P. (2007). Closing product information loops with product-embedded information devices: RFID technology and applications, models and metrics. In RFID technology and applications. New York: Cambridge University Press, pp. 169-18I.

MAGAL, S.R., Feng, M., Essex, P.A. (200I). An exploratory study of a web-based electronic commerce application. Journal of Information Technology Theory and Application, 3(5), I-24.

MAK, S. (200I).A model of information management in construction using information technology.Automation in Construction, I0(2), 257-263.

MARTIN, J. (2003). E-procurement and extranets in the UK construction industry. In Proceedings of the 125th FIG Working Week, Paris, France, April 2003.

MASTERMAN, J.W. E. (2002). Introduction to building procurement systems. Taylor \& Francis, London.

MASTURA, J., Ramayah, T., Abdul-Rashid, A., Basri, S. (2007). Technology readiness among managers of Malaysian construction firms. Engineering, Construction and Architectural Management, I4(2), |80-I9|.

MENTZER,J.T. (200I). Supply chain management. Sage Publications, Thousand Oaks.

MILES, M.B., Huberman, A.M. (1994). Qualitative data analysis. Sage Publications, Thousand Oaks.

MOTAMEDI, A., Hammad, A. (2009). RFID-assisted lifecycle management of building components using BIM data. In Proceedings of the 26th International Symposium on Automation and Robotics in Construction (ISARC 2009), Austin, USA, June 2009.

NCCTP, (2006). Proving Collaboration Pays - Study Report, NCCTP, http:// www.ncctp.net. [Accessed Septembre 19, 20I2].

NGAI, E.W.T., Moon, K.K.L., Riggins, F..,Yi, C.Y. (2006). RFID research:An academic literature review (1995-2005) and future research directions. International Journal of Production Economics, II2(2), 5I0-520. 
NONAKA, I. (1994). A dynamic theory of organizational knowledge creation. Organization Science, 5(I), I4-37.

ORGANISATION FOR ECONOMIC CO-OPERATION AND DEVELOPMENT, (2008). Competition in the construction industry.

http://www.oecd.org/dataoecd/32/55/41765075.pdf.

[Accessed January 15, 20I2].

OLUGBODE, M., Rhodri, R., Biss, T. (2007). The role of information technology in achieving the organisation's strategic development goals: A case study. Journal of Information Systems, 32(5), 64I-648.

OYE, N.D., Inuwa, I., Shakil, A.M. (20I I). Role of information communication technology (ICT): implications on unemployment and Nigerian GDP. Journal of International Academic Research, II(I), 9-17.

PEANSUPAP, V., Walker, D. (2005). Factors affecting ICT diffusion: A case study of three large Australian construction contractors. Engineering, Construction and Architectural Management, I2(I), 2I-37

RADOSAVLJEVI, M. (2007). How could the construction supply chain benefit from RFID/GPS integration: A knowledge management perspective. In Proceedings of the CIB WI02 3rd International Conference, Stuttgart, Germany.

REICH, B.H., Gemino, A., Sauer, C. (20I2). Knowledge management and project-based knowledge in it projects:A model and preliminary empirical results. International Journal of Project Management, 30(6), 663-674.

REN, Z., Anumba, C.J., Tah, J. (20II). RFID-facilitated construction materials management (RFID-CMM) - A case study of a water-supply project. Advanced Engineering Informatics, 25(2), 98-207.

ROSLI, A.R., Taib, I.M.,Wan, B.,Wan, A., Nasid, M.A.,Wan, N., Wan, A., Zainordin, Z.M. (2006). Effect of procurement systems on the performance of construction projects. Padang, Indonesia.

SARDROUD, M., Limbachiya, M.C. (20I0). Improving construction supply chain management with integrated application of RFID technology and portal system. In Proceedings of the 8th International Conference on Logistics and SCM Research (RIRL 20I0), Bordeaux, France, September 2010.

SCHULTMANN, F., Sunke, N. (2008). Life cycle information of buildings supported by RFID technologies. Ist International Conference on Industrialised, Integrated, Intelligent Construction (I3CON), Loughborough, UK, May 2008.
SHIN, T.H., Chin, S., Yoon, S.W., Kwon, S.W. (20I I).A serviceoriented integrated information framework for RFID/WSNbased intelligent construction supply chain management.Automation in Construction, 20(6), 66I-740.

SONG, J., Caldos, C., Ergen, E., Haas, C., Akinci, B. (2004). Field trials of RFID technology for tracking prefabricated pipe spools. In Proceedings of the 2 I st International Symposium on Automation and Robotics in Construction (ISARC 2004), Jeju, Korea, September 2004.

STEWART, R.A. (2007). IT enhanced project information management in construction: Pathways to improved performance and strategic competitiveness. Automation in Construction, I6(4), $5 \mathrm{II}-5 \mathrm{I} 7$.

STUCKHART, G. (1995). Construction materials management.Marcel Dekker, Inc., New York.

TOLSON, S. (2007). Procurement and supply contracts in the construction industry.

http://www.fenwickelliott.co.uk. [Accessed January 25, 20I2].

TZENG, C.T., Chiang, Y.C., Chiang, C.M., Lai, C.M. (2008). Combination of radio frequency identification (RFID) and field verification tests of interior decorating materials. Automation in Construction, I8(I), 16-23.

VAN GASSEL, F., Glenco, J. (2008). A simulation tool for radio frequency identification construction supply chains. In Proceedings of the 25th International Symposium on Automation and Robotics in Construction (ISARC-2008), Vilnius, Lithuania, June 2008.

VANITA, A., Yang, J., Ravi, S. (2009) Study of ICT adoption for building project management in the Indian construction industry. Automation in Construction, I8(4), 4I5-423.

VIJAYARAMAN, B.S., Osyk, B.A., and Chavada, D. (2008). An exploratory study of RFID adoption in the paperboard packaging industry. Journal of Technology Management \& Innovation, 3(4), 95-II0.

WAMBA, S.F., Lefebvre, L. A., and Lefebvre, E. (2007). Integrating RFID technology and EPC networks into a B2B retail supply chain: A step toward intelligent business processes. Journal of Technology Management \& Innovation, 2(2), I I4124.

WANG, L. (2008). Enhancing construction quality in management using RFID technology. Automation in Construction, 17(4), 467-479. 
WANG, L., Lin, Y., Pao, H. (2007). Dynamic mobile RFIDbased supply chain control and management system in construction. Advanced Engineering Informatics, 2 I (4), 377-390.

WEN, L., Zailani, S., Fernando, Y. (2009). Determinants of RFID adoption in the supply chain among manufacturing companies in China: A discriminatory analysis. Journal of Technology Management \& Innovation, 4(I), 22-32.

WILKINSON, P. (2005). Construction collaboration technologies:The extranet revolution. Taylor \& Francis, London.

WILLIAM, J. P. (2006). Collaboration in the supply chain speeds innovation. http://www.industryweek.com. [Accessed January 27, 2012].

WILLIAMS, T., Bernold, L., Lu, H. (2007). Adoption patterns of advanced information technologies in the construction industries of the United States and Korea. Journal of Construction Engineering and Management, I33(I0), 780-790.

WING, R. (2006). RFID applications in construction and facilities management. Electronic Journal of Information Technology in Construction, II, $7 \mathrm{I}$ I-72I.

XUE, X.L., Li, X.D., Shen, Q.P., Wang, Y.W. (2005). An agentbased framework for supply chain coordination in construction. Automation in Construction, I4(3), 4I3-430.

XUE, X.L., Wang, Y.W., Shen, Q.P. (2007). The application of ICT in collaborative working in construction projects: A critical review. In Proceedings of the 2007 International Conference on Convergence Information Technology (ICCIT 2007), Jeju Island, Korea, November 2007.

YABUKI, N., Oyama,T. (2007).Application of radio frequency identification technology for management of light weight temporary facility members. In Proceedings of the 2007 ASCE International Workshop on Computing in Civil Engineering, Pittsburgh, USA, July 2007.

YIN, R.K. (1994). Case study research: Design and methods. Sage Publishing, Thousand Oaks.

ZACK, M.H. (2002). Developing a knowledge strategy: Epilogue. In The strategic management of intellectual capital and organizational knowledge: A collection of readings. Oxford, UK: Oxford University Press, pp. 255-268.

ZIETSMAN, E. (2007). How can information and communication technology reduce inefficiencies in the construction industry? http://www.cib2007.com. [Accessed January 27, 2012]. 